\title{
HARMONILINTAS AGAMADIMEDIAMASSA
}

\author{
Oleh:Mohamad Ali Hisyam*
}

\section{Abstract}

The article is intended to elaborate the problems of dialogue among religions in mass media discourse that is occurred in Indonesia within last few years. At the end, it tries to offer alternative solutions that may be suitable with the problem. The analysis indicates that mass media has a strategic role to support the dialogue. However, the role should be followed by the awareness of the mass media to be consistent and commited to maintaining the barmony among religions. The mass media should not change its objective.

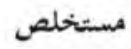

تحاول المقالة الحالية صياغة مشكلة الحوار بين أتباع الديانات المخلتفة في الخطاب الإعلامي في إندونيسيا في

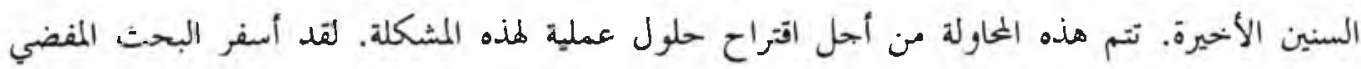

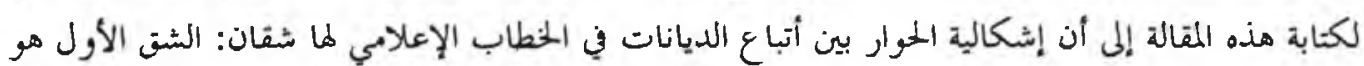

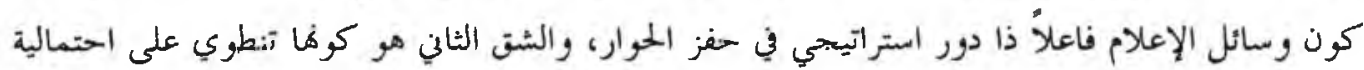
حرف مسار هذه العلاقة الحوارية نو نفق مظلم مليء بكظاهر عدم التناغم بين أتباع الديانات المختلفة

Keyword: Media Massa, Agama, Dialog

\section{A. Pendahuluan}

Harus diakui bahwa media massa dengan segala peran yang dijalankannyalangsung atau tidak- telah melahirkan berbagai akses, baik positif maupun negatif. Komunitas beragama di Indonesia yang terlibat dalam interaksi sosial mesti mengambil sisi positif dari tampilnya media sebagai garda yang mencoba menggelar dialog antaragama yang kondusif dan akomodatif. Harapan penuh kedamaian seperti ini akan mudah dan senantiasa terjawab dengan tandas manakala ada upaya yang serius dan kompak untuk benar-benar mewujudkan masyarakat beragama (religion society) yang plural dan damai. Bukan malah dengan mengelak dan menyodorkan sanggahan retoris yang cenderung dekoratif dan apologis belaka.

\footnotetext{
•Dosen Universitas Trunojoyo Madura. Email: morlaok@yahoo.com
} 
Selama ini simtom yang menggambarkan adanya kecenderungan saling tuding dan bermain prasangka telah bernas terpampang di depan mata. Adanya gejala untuk terus menerus menciptakan musuh-musuh semu (pseudo-enemis) dan kemudian gembar-gembor memeranginya, terbukti telah banyak menguras energi dan pikiran masyarakat, yang hingga kini tak kunjung berbuah pada terciptanya kondisi sosial keagamaan yang teduh lagi dinamis. Bagaimanapun juga, menampilkan agama dalam wajah kultural dan dialogis merupakan salah satu bentuk kongkret dari adanya kesalehan modernitas. ${ }^{1} \mathrm{Hal}$ semacam ini menjadi dambaan banyak orang, ketika agamaagama sibuk menampakkan mukanya dalam bentuk yang garang dan beringas. Namun perlu diingat, wacana dialogis semacam ini hanya bisa dimulai dengan adanya keterbukaan dari masing-masing agama.

Tulisan ini bermaksud memetakan problema dialog antaragama dalam diskursus media massa, khususnya yang terjadi di Indonesia beberapa tahun belakangan, untuk kemudian mencoba menawarkan pintu-pintu solusi yang mungkin diwujudkan. Bahwa media memiliki peran strategis guna menggalang dialog, mesti diimbangi dengan kesadaran yang menggambarkan jika media juga mempunyai peluang untuk membelokkan arah hubungan lintas agama menuju koridor yang cenderung negatif dan berpotensi menghadirkan disharmoni. Kepentingan, tendensi, serta sentimen sosial yang subjektif adalah beberapa faktornya. Optik yang seimbang dalam memandang serta menyajikan suguhan jurnalisme humanis, merupakan jalur guna mengawal visi media pada jalur yang luhur.

Sepanjang lintasan sejarah, upaya-upaya mulia untuk memadukan agama-agama dalam sebuah payung dialog yang harmonis, tak pernah sepi dari penghalang. Tidak sedikit sekat-sekat sosial dalam beragam bentuk dan motifnya yang senantiasa menjadi bayangan buruk yang mengganggu terciptanya dialog kondusif tersebut. Kemajemukan sosial, dalam hal ini, juga telah melahirkan kemajemukan kendala yang kerapkali sukar diatasi. Di antara beberapa sekat tersebut adalah beragam faktor sosial yang terus hadir seiring akrobatisasi zaman. Mulai dari faktor politik, geografis, ekonomis hingga faktor penguasaan (baca: politik propaganda) media massa yang sarat muatan kepentingan tertentu.

\section{B. Konflik dan Emosi Publik}

Dalam melayani masyarakat, media massa memiliki empat peran yang niscaya harus dijalankan. Pertama, sebagai penebar informasi (to inform). Kedua, sebagai

${ }^{1}$ Zuly Qodir, Agama Dalam Batyang-Bayang Kekuasaan, (Yogyakarta:Dian/Interfidei. 2001), hal. 101. 
sarana pendidikan (to educate). Ketiga, sebagai wadah untuk menyajikan aneka hiburan (to entertain). Dan keempat, ia bisa menjadi ajang untuk saling mempengaruhi (to influence). ${ }^{2}$ Pertanyaannya kemudian, bagaimana cara media menjalankan keempat peran tersebut? Dalam pandangan Sam Abede Pareno, pers tidak bisa hanya mengakomodasi sebagian dari keempatnya. Walaupun dengan dalih spesialisasi dan tuntutan keadaan, pengabaian salah satu atau seluruhnya dapat dikategorikan sebagai "pengebirian" peran pers dalam makna yang luas. ${ }^{3}$ Artinya, peran-peran tersebut mutlak dijalankan secara komprehensif.

Dalam kerangka dialog antaragama, ada beberapa fungsi strategis yang bisa diemban oleh media massa. Pertama, secara kolektif ia bisa berperan untuk melacak dan menghimpun data-data keagamaan (teks, manuskrip, dan sebagainya) sebagai warisan khazanah bagi kemaslahatan bersama. Pada konteks ini, pers dapat menjadi media penyebar informasi dan pengetahuan tentang suatu agama kepada pemeluknya ataupun kepada komunitas lain yang membutuhkannya.

Kedua, media bisa menjelma agen dialog yang aktif, komunikatif, dan partisipatif bagi kepentingan khalayak. Daya ungkap dan jarak jangkaunya yang canggih, ditambah kekuatan naratifnya yang kuat serta efek massif dan kumulatifnya yang dahsyat, ia sebisa mungkin digunakan sebagai ajang melayani khalayak melalui sajian gagasan yang ditawarkannya. Di titik ini, adanya keterbukaan, kesadaran akan pluralitas, serta sikap netral, menjadi prasyarat yang tak tertawar untuk diwujudkan. Demi mengemban misi dialog lintas agama yang damai, media massa tak boleh berpihak (partiality). Keberpihakan hanya akan mengaburkan obyektivitas, menimbun fanatisme, dan mengurangi keberimbangan informasi yang selayaknya dikemas media. ${ }^{4}$

Persoalan bahwa media memiliki kecenderungan untuk mengajak dan mempengaruhi, sesungguhnya tak perlu dirisaukan bilamana ia dijalankan melalui koridor

${ }^{2}$ Onong Uchyana Effendy, Ilmu Komunikasi: Teori dan Praktek. Bandung: Remaja Rosdakarya, 2000, hal. $149-150$.

${ }^{3}$ Bandingkan Sam Abede Pareno, Media Massa: Antara Realitas dan Mimpi Surabaya: Penerbir Papyrus, 2005, hal. 07-08.

4 Secara perlahan, media bertugas mengikis prasangka-prasangka yang mengendap pada tiap komunitas beragama yang cenderung menisbatkan kesalahan pada pihak lain dan selalu melihat dirinya dalam posisi yang benar sepenuhnya. Cara pandang teologis yang tunggal dan antidialog yang menebal di bawah lapisan substratum bawah sadar penganut agama, haruslah diupayakan untuk hilang. Salah satu alat untuk itu adalah media massa. Lihat Ulil Abshar-Abdalla, Membakar Rumab Tuban: Pergulatan Agama Privat dan Publik (Bandung: Rosdakarya, 1999), hal, 41. 
dan kode etik yang sesuai aturan dan saling menghormati. ${ }^{5}$ Kekuatan media yang dalam beberapa hal menembus ruang dan waktu, mampu menyajikan aspek-aspek fenomenal keagamaan seperti cult (aktivitas ritual), code (norma sosial), community (kesekutuan internal) maupun creed (doktrin formal) dalam sebuah kemasan yang utuh dan komprehensif. ${ }^{6}$ Daya cakup semacam ini secara strategis dapat dijadikan sebagai sarana untuk bertukar pandang dengan komunitas agama lain.

Ketiga, media berkemampuan menjadi wahana komunikasi berbagai pihak. Pada ruas ini, ia mampu membantu menghapus adanya kesalahpahaman dalam beragam bentuknya (miskonsepsi, stigmasi, purbasangka, stereotyping) sehingga pada akhirnya mampu membungkam teriakan khalayak (public outcry) dengan solusi yang tepat dan tidak distorsif. Dalam kaitan ini, keberagaman potensi agama tak harus disajikan dalam diktum yang "seragam", akan tetapi ditampilkan menjadi tampilan yang konfiguratif, dinamis, dan harmonis.

Keempat, media bisa dijadikan ajang runding antaragama. Guna menyusun agenda sosial bersama (platform) ke muka, andil strategis media bisa dimanfaatkan oleh kalangan agama. Sebagai sarana alternatif, ia dapat dijadikan jembatan publikasi dan sosialisasi kontekstual dari sebuah langkah kebersamaan agar mampu ditangkap dan tidak disalahpahami publik. Selama ini terlanjur beredar stigma negatif seputar media yang dianggap partisan dan menonjolkan keterwakilan golongan tertentu. ${ }^{7}$ Keadaan ini jelas merupakan dilema bagi pers. Di satu sisi ia dituntut menyuguhkan informasi yang obyektif dan simpatik. Sementara di sisi yang lain, preferensi pembaca tradisional yang diwakilinya juga menuntut untuk diakomodasi dengan baik. ${ }^{8}$ Kecenderungan serta fanatisme yang demikian sangat tampak ketika media-media tersebut memberitakan kasus kemanusiaan di seputar konflik-konflik bernuansa Suku, Agama, Ras, dan Antargolongan (SARA).

${ }^{5} \mathrm{Dalam}$ khazanah Islam, hal ini disebut dengan visi dakwah, mengajak menuju kebaikan. Dalam Al-Qur'an (QS.16:125) terlampir beberapa tahapan dakwah yang semuanya bisa dipratikkan secara aplikatif lewat media.

${ }^{6}$ Muhammad Sofyan, Agama dan Kekerasan dalam Bingkai Reformasi Jakarta: Yayasan Adikarya Ikapi-The Ford Fondation, 1999, hal. $\mathrm{x}$.

${ }^{7}$ Sejauh ini, terdapat sejumlah media (terutama cetak) yang oleh sebagian kalangan dianggap sebagai representasi dari wakil golongan (agama) tertentu. Republika, Suara Hidayatullah, Media Dakwah, Sabili dan Pelita adalah sebagian contoh dari media yang berafiliasi pada kepentingan umat Islam. Sementara Kompas, Suara Pembaruan, Sinar Harapan dan Basis merupakan sebagian duta dari media milik kaum Nasrani. Kendati saat ini jurnalisme yang diusung kebanyakan media tersebut sudah sangat pluralis dan inklusif, generalisasi stigmatis seperti ini susah untuk dihilangkan begitu saja.

${ }^{8}$ Agus Sudibyo, Politik Media dan Pertarungan Wacana (Yogyakarta: LkiS, 2001), hal. 11. 
Berlatar realitas di muka, media massa tak pelak merupakan jembatan yang bisa menghuburıgkan kepentingan lintas agama dalam wujud yang dinamis dan positif. Namun demikian, sulit disangkal bahwa dengan keberadaannya sebagai penyebar kabar, media juga dapat berperan mengobarkan aneka prasangka, ${ }^{9}$ termasuk prasangka antaragama secara subyektif-emosional.

Oleh karenanya, dirasa penting bagaimana mekanisme penanganan konflik yang melibatkan media dan masyarakat pembacanya. Dibentuknya Dewan Pers merupakan sebagian solusi untuk menengahi problema ini. Dewan Pers salah satu tugasnya dimaksudkan guna melakukan negoisasi dengan jalan memberi hak jawab atau somasi apabila ada individu atau kelompok masyarakat yang merasa dirugikan oleh media, sehingga tidak langsung mengadukannya ke pengadilan. Tugas utama Dewan ini adalah memelihara kebebasan pers dan menjaganya dari kemungkinan intervensi dari pihak luar. ${ }^{10}$

Sebagai segmen utama media, masyarakat hendaknya peka, kritis, dan berkesadaran melek media. Sedangkan pada belahan yang lain, pers juga mesti memiliki kesadaran untuk menyajikan jurnalisme yang etis dan mencerahkan. Dalam bahasa yang lugas, keadaan inilah barangkali yang disebut dalam istilah Franz Magnis-Suseno dengan etika keselarasan. Etika ini berupa sebuah formulasi dengan batasan dan tata perilaku sosial yang mengedepankan keserasian, keseimbangan, atau harmoni sosial dengan cara dan tujuan untuk menghindari kemungkinan terjadinya konflik. ${ }^{11}$

Dalam lingkup konflik antaragama, beragam elemen sosial di atas seringkali dibungkus oleh media menjadi sajian berita yang kadangkala bias dan kabur. Sebuah konflik yang murni bermotif politik, misalnya, dalam hidangan media tiba-tiba berubah wajah menjadi konflik agama. ${ }^{12}$ Weinata Sairin berpendapat bahwa media

${ }^{9}$ Sehalus apapun, prasangka (prejudice) tetap bisa dirasakan dan dideteksi kendati hal itu teramat sulit. Sejauh ini, prasangka menupakan konstruk terpenting guna memahami hubungan antarkelompok, termasuk kelompok agama. Sebagaimana dikutip Agus Sudibyo, bahkan Gordon Allport, sang pelopor kajian prasangka pun kesulitan untuk memetakannya. Secara illustratif, Allport menggambarkan kesulitan pemecahan soal prasangka sebagai "lebih sulit dari memecahkan rahasia atom. Dalam The Nature of Prejudice, Allport mengemukakan: "It required years of labor and billions of dollars to uncover the secret of the atom. It will take still a greater investment to gain the secrets of man's irrational nature. It is easier, some one bas said, to smash an atom than prejudice". Bandingkan Agus Sudibyo, Kabarkabar Kebencian. Prasangka Agama di Media Massa Jakarta: ISAI, 2001, hal. 31.

10 "Dewan Pers Bisa Jembatani Konflik Masyarakat-Pers", Kompas, 30 Agustus 2003.

${ }^{11}$ Franz Magnis-Suseno, Etika Jawea: Sebuab Analisa Filsafati tentang Kebijaksanaan Hidup Jawea, Jakarta: Gramedia Pustaka Utarna, 1985, hal. 67.

${ }^{12}$ Padahal dalam pandangan Weinata Sairin, konflik agama sesungguhnya tak pernah ada karena dalam konflik tersebut tak terdapat pertikaian dalam bidang teologi. Sairin lebih cocok menyebutnya 
sebenarnya dapat berperan untuk meredam konflik, bukan malah sebaliknya ikutikutan menyalakannya.

Sairin kemudian merekomendasikan lima cara sebagai resolusi guna menanggulangi konflik seperti ini. Pertama, penyadaran akan adanya kemajemukan. Kedua, perlu dirumuskan secara jelas hubungan agama dan negara dalam konteks falsafah hidup berbangsa (Pancasila). Ketiga, otonomi agama yaitu eksistensi agama tidak perlu berdasarkan kebijakan negara. Keempat, perlu dibentuk wadah kerja sama lintas agama hingga ke tingkat akar rumput seperti kabupaten/kecamatan. Kelima, membuka kotak SARA sebagai ajang berbagi saran. ${ }^{13}$ Dari kelima cara ini, media dapat berpartisipasi aktif, lebih-lebih sebagai wahana sosialisasi penyadaran perihal kemajemukan (pluralisme) hidup beragama.

\section{Ruang dan Peluang Dialog}

Bagaimana seharusnya media massa berperan dalam dialog lintas agama? Pertanyaan ini penting untuk dijawab guna memenuhi harapan masyarakat terhadap media dalam andilnya sebagai penopang demokrasi dalam kehidupan sosial yang multiwajah. Sudah semestinya media meneguhkan perannya sebagai pemelihara ruang dialog yang memungkinkan semua kelompok masyarakat berpikir jernih dan bertindak sebagai warga bangsa dan manusia yang merdeka dan bertanggung jawab. Keinginan semacam ini perlu terus didengungkan lantaran saat ini pers masih cenderung menjadi bagian dari kelompok elite politik dan ekonomi serta kurang memberikan tempat kepada rakyat. ${ }^{14}$

Alih-alih menyediakan ruang dialog, pemberitaan tentang konflik sosial di media massa cenderung membentuk stigma antarkubu dan menghilangkan nurani kebudayaan (cultural conscientia) dari kelompok yang terlibat konflik. Pemuatan berita yang kurang tepat mengakibatkan kekejaman sebagai manifestasi konflik, secara tidak disadari berpindah dari ruang sosiokultural ke ruang media. Dengan demikian, konflik dan kekerasan hanya mengalami transformasi ruang. Pada saat yang bersamaan, pelaku konflik belum tentu memiliki akses yang memadai ke ruang media. Bahkan terdapat kecenderungan bahwa justru para politisi yang kemudian mengambil-alih pengembangan isu konflik dan mengelola akses ke media atau bisa juga sebaliknya.

dengan konflik bernuansa agama. Sebagai contoh adalah Peristiwa Ambon. Lihat "Penyelesaian Konflik Antaragama Melalui Hubungan Pribadi", Kompas, 02 November 2000.

${ }^{13} \mathrm{Ibid}$.

14 "Media Massa Cenderung Hilangkan Nurani Kultural", Kompas, 04 Mei 2001. 
Media malah menyuguhkan fokus pada politisi. Aspek lain dari pemberitaan media tentang konflik dan kekerasan berkaitan dengan kebutuhan akademisi dan komentator lainnya, yang melahirkan sialng opini para pakar. Media massa kemudian menjadi "arena perang tanding" bagi para pakar atau kelompok oportunis. ${ }^{15}$

Asumsi lain bahwa media cenderung mengobarkan pertikaian adalah fenomena kedekatan antara media dengan terorisme. Media massa, sebagaimana tudingan sinis Margaret Thatcher, adalah sahabat baik teroris. Medialah pemasok oksigen publisitas yang amat diperlukan teroris. Media membuat tugas teroris menjadi mudah dengan cara menyebar kekerasan dan menebar ketakutan. Media massa modern, lebih-lebih dengan kemampuan siaran langsungnya, memainkan peran amat vital dalam menyiarkan pesan teroris itu. Tanpa liputan media, dampak kekerasan itu hanya terbatas pada korban dan sasaran langsung. Ia tidak bisa mencapai sasaran lebih luas ke tempat yang sebetulnya tindakan itu dimaksudkan. ${ }^{16}$

Pakar komunikasi sudah sejak lama menyimpulkan, terorisme dan media telah bekerja sama saling menguntungkan. Teroris membutuhkan media massa untuk menyampaikan pesan dan tuntutannya, sedangkan media memerlukan teroris untuk asupan berita. Teroris selalu menyerang sasaran dan simbol-simbol (semisal gedung WTC dan Pentagon di Amerika serta hotel JW Marriott di Indonesia) yang bisa menjadi fokus perhatian media. Atas dasar melayani hak masyarakat guna mengetahui (people right to know), media mengutip begitu saja aneka pernyataan yang dikeluarkan musuh-musuh negara maupun para penggadai agama.

Muncul kemudian solusi agar media massa memboikot dengan tidak memberitakan kekerasan teroris. Usul yang sering disebut sebagai counterterrorist strategy. Boikot pemberitaan itu membuat teroris yang lapar publisitas untuk menyampaikan pesannya kepada sasaran lebih luas menjadi gagal, karena terornya hanya terbatas pada sasaran langsung. Aliran oksigen publikasi kepada teroris menjadi terputus, agar

\section{${ }^{15} \mathrm{Ibid}$.}

16 "Without media there can be no terrorism", demikian bunyi sebuah slogan kemanusiaan. Hanya dengan penyebarluasan teror dan kemarahan terhadap sasaran lebih luas, teroris bisa mencapai tingkat maksimum posisi tawar yang mereka perlukan guna mempengaruhi perubahan politik secara fundamental. Kelompok Jamaah Islamiyah (II) yang mengklaim bertanggung jawab atas peledakan bom di Hotel JW Marriott Jakarta, misalnya, mengatakan teror yang mereka tebarkan merupakan peringatan berdarah kepada Presiden Megawati Soekarnoputri untuk tidak memerangi para militan. "Ini pesan untuk Megawati dan seluruh musuh-musuh kami, bila mereka mengeksekusi saudara-saudara Muslim kami, kami akan terus melancarkan kampanye teror di Indonesia dan kawasan ini." Begitulah ancaman seorang operator $\Pi \mathrm{I}$ kepada Straits Times, sebuah media cetak yang terbit di Singapura. 
aparat penegak hukum lebih fokus bekerja membongkar jaringan dan menghukum pelakunya. ${ }^{17}$

Dari sini, tampak jelas bahwa dalam merealisasikan dialog antaragama, media memiliki orientasi ganda. Di satu sisi, ia strategis bertindak sebagai mediasi, namun di kutub yang lain ia juga demikian mudah menghancurkannya. Ulil Abshar-Abdalla mengurai sejumlah kendala pokok dialog lintas agama di Indonesia ke dalam tujuh kotak. Pertama, sifat elitis. Masalah dialog secara nyata mulai berarak menuju level akar rumput, sehingga perhatian harus mulai diarahkan ke sana. Dialog sudah selayaknya mulai menyertakan kaum awam, dan tidak melulu menjadi "kemewahan" bagi elite agama yang terpelajar. Kedua, kurang militan. Dibanding dengan sejumlah aktivis lain yang berjuang untuk isu HAM, lingkungan, perempuan, pendidikan sipil (civic education), dan lain-lain, para aktivis dialog antaragama kurang agresif dalam mengampanyekan isu tersebut. Tampaknya ada semacam keengganan untuk memasuki wilayah dialog antaragama, karena sifatnya yang "sensitif".

Ketiga, jalur eceran. Aktivis dialog antaragama harus berupaya merebut dan menandingi “ jalur eceran” yang selama ini dimanfaatkan pengusung konservatifisme agama yang antidialog. Jalur semacam ini sudah amat mengakar di lapisan khalayak. Keempat, infrastruktur. Selain dibangun melalui seremoni dan tindakan-tindakan intelektual yang bersifat diskursif, dialog membutuhkan Infrastruktur pokok yang jelas, utamanya berkenaan dengan penyelesaian konflik. Kelima, perang prasangka. Kini sudah waktunya menghapus sikap alergi dan silang prasangka antara kubu pro-dialog dan kelompok konservatif, dengan cara tidak lagi saling melempar tuduhan "sesat".

Keenam, ketidakadilan, khususnya di aspek ekonomi. Dialog bukanlah "alat politik" untuk menutupi suatu ketidakadilan. Artinya, dialog mensyaratkan "basis materiil" yang memadai, di mana kubu-kubu yang selama ini mengalami deprivasi ekonomi mesti mendapatkan haknya secara proporsional dan akhirnya menerima dialog sebagai opsi yang solutif. Ketujuh, dialog internal. Secara sosiologis, umat beragama tidak monolitik, tetapi beragam dan mengalami fragmentasi internal yang cukup tajam. Pluralisme tidak saja terjadi dalam konteks eksternal, namun juga dalam internal suatu agama. Dialog internal akan memudahkan dialog eksternal, dan bukan sebaliknya. Pada titik tertentu, dialog internal agama acap lebih rumit ketimbang dialog antaragama. ${ }^{18}$

Pemetaan Ulil ini, pada spektrum yang lebih luas, mengantar kesadaran kita menuju peran vital media. Sejumlah kendala tersebut adalah keberserakan faktor

${ }^{17}$ Lihat T. Yulianti, "Saatnya Media Memboikot Teroris", Kompas, 09 agustus 2003.

${ }^{18}$ Ulil Abshar-Abdalla, "Beberapa Kendala Praktis Dialog Antaragama", Kompas, 05 Agustus 2000. 
yang sesungguhnya dapat dibantu oleh media untuk menyatupadukannya dalam rangka tercapainya pertemuan (encounter) dialogis antaragama. Persoalannya, mengapa media massa justru gagal memberikan kontribusi memadai bagi harapan luhur tersebut? Kegagalan media dalam melempangkan harmoni antaragama, merupakan cermin dari ketidaksuksesan para jurnalis kita dalam mengasah kepekaan sosial. Dalam fungsinya sebagai "mata-telinga" masyarakat, jurnalis cenderung tidak menempatkan media dalam lingkaran pemecah masalah konflik antaragama.

Secara sederhana, tugas jurnalis pada aras ini bukan lagi sekadar menyajikan berita faktua ${ }^{19}$ dengan segenap kriteria newswortby namun juga bertindak sebagai intelektual yang meneropong sebuah peristiwa dari perspektif kemasyarakatan. Penting diingat paradigma yang menandaskan bahwa sebuah fenomena tidak berdiri dalam kevakuman, melainkan mengandung latar belakang, keterkaitan, kelanjutan, serta dampak. Betapapun, suatu konflik bukanlah hal yang muncul tiba-tiba. Ada indikator dan proses panjang yang mengiringinya. Media massa, pada titik ini, acap gagal berperan sebagai sumber sinyal. Gagalnya peran early warning system pada media ini ditengarai turut menipiskan kewaspadaan masyarakat terhadap lahirnya konflik.

Menyikapi pelbagai kendala ini, tak bisa tidak semua elemen masyarakat dari berbagai kubu dan strata harus tetap meretas dan melanjutkan upaya ke arah dialog. Dalam beragam formatnya, dialog merupakan lingkar pemersatu bagi berbagai jenis peradaban untuk bersua dan bercengkerama. Kerjasama antarmedia pada konteks ini juga layak menjadi pagar penopang. Langkah menyatukan kaum jurnalis antaragama kiranya strategis sebagai solusi yang membuka peluang pemaduan visi dalam mengembangkan dialog serta mengelola konflik. ${ }^{20}$ Dari sini, akan tumbuh kesadaran untuk menyuburkan ruang dialogisme ${ }^{21}$ yang dinamis di tengah masyarakat plural.

\footnotetext{
${ }^{19}$ Media massa sebagai penyalur informasi memproduksi dua ragam informasi, yakni informasi faktual (karya jumalistik) serta informasi fiksional (karya sastra). Pada penerapannya, media harus lebih banyak menyajikan informasi faktual dalam proporsi yang layak dan dominan. Bandingkan Veven SP Wardhana, "Personalitas itu Sakit Jiwa", Kompas, 08 Mei 2005.

${ }^{20}$ Kerjasama dimaksud bisa berupa kerja-kerja kejurnalistikan yang saling menyapa, semisal pelatihan jurnalis antaragama, perilisan film bersama, sharing dan tukar pengalaman, forum seminar bersama, serta aneka kerja praktis-profesional lainnya. Baca Parni Hadi, "Islam and the West One Year After 11 September 2001: Obstacles and Solutions in Search for New World Civilization Media and Politics of Making Image" dalam Dick Van der Meij (ed.), Islam and the West: Obstacles and Solutions in Search for a New World Civilization (Jakarta: CLC UIN Jakarta dan Konrad-Adenauer Stiftung Coorporation, 2003), hal. 39-50.

${ }^{21}$ Dialogisme lazim diartikan sebagai sebuah sikap dan proses saling menghargai antarmanusia. Sifatnya yang simetris memungkinkan manusia bisa mengenal yang lainnya (the others). Dialogisme
} 


\section{Jurnalisme Damai}

Sebagai pewarta kebenaran, media massa dituntut mengungkapkan segenap fakta, segetir apapun ia. Berbagai konflik kemanusiaan yang bernuansa agama, misalnya, mesti ia paparkan apa adanya. Namun demikian, seorang jurnalis tetaplah manusia biasa yang pada dimensi lain dalam dirinya masih menampakkan suara nurani yang pekat. Artinya, sebagai sebuah gejala dan ironi kemanusiaan, beragam konflik kemanusiaan tentu tak dinginkan oleh siapapun untuk terulang kesekian kali. Tepat di garis ini, jurnalisme damai (peace joumalism) menjadi bukan sekadar wacana retoris yang dihembuskan kalangan media, melainkan merupakan tuntutan sekaligus tuntunan bagi para pecinta dialog dan kedamaian untuk diterapkan secara nyata di tengah masyarakat.

Secara sederhana, jurnalisme damai dapat diartikan sebagai suatu praktik jurnalistik yang bersandar pada pelbagai pertanyaan kritis tentang manfaat aksi-aksi kekerasan dalam sebuah konflik serta perihal hikmah di balik konflik itu sendiri bagi entitas kemanusiaan. Jurnalisme damai memandang konflik sebagai tragedi kemanusiaa yang tak seharusnya terjadi. Ia pun pada dasarnya merupakan seruan kepada semua pihak untuk merenungi kerugian dan jatuhnya korban yang bisa ditimbulkan akibat konflik, baik itu psikologis, budaya, dan struktur sosial. ${ }^{22}$

Bila ditilik secara historis-formal, istilah jurnalisme damai pertama kali muncul menjadi wacana serius dalam kegiatan Kursus Jurnalisme Perdamaian yang diadakan di Taplow Court, Buckinghamshire Inggris pada 25-29 Agustus 1997. Ia dicetuskan sebagai kritik terhadap kecenderungan jurnalisme perang yang digembar-gemborkan pers Barat. Sebagaimana diketahui, media-media Barat dalam meliput perang terbiasa dengan pola yang menempatkan konflik sebagai semata persoalan "menang-kalah" layaknya pertandingan olahraga. ${ }^{23}$ Pemberitaan yang dihidangkan terlalu terpusat pada aksi-aksi kekerasan yang mewarnai konflik, tanpa sudi untuk lebih lanjut mengkaji akar konflik, dampak, serta solusi pencegahannya. Akibatnya, jurnalisme perang

mampu melahirkan kehendak untuk memecahkan persoalan bersama (the common problems) dan bukan kehendak untuk saling menekan dan menguasai pihak lain. Lihat Yasraf Amir Piliang, Hipermoralitas: Mengadili Bayang-bayang (Yogyakarta: Penerbit Belukar, 2003), hal. 130-131.

${ }^{2}$ Agus Sudibyo, Politik Media dan Pertarungan Wacana. Yogyakarta: LkiS, 2001, hal. 167.

${ }^{23}$ Ibid. Namun demikian, secara informal jurnalisme damai sudah mulai berkembang dan dipraktikkan sejak awal tahun 1970-an (salah satu tokoh penting yang memomulerkan istilah ini adalah profesor studi perdamaian terkemuka, Johan Galtung) dan disosialisasikan secara intensif di berbagai negara di dunia, khususnya di wilayah-wilayah konflik, mulai akhir tahun 1980-an. Bandingkan Maria Hartiningsih, Jumalisme Damai Multikultural. Bogor: Makalah Diklat Jumalisme Dakwah ICIP, 2005, hal.3. 
ala Barat tak ubahnya exposing yang kian mengobarkan semangat perselisihan dan kebencian.

Di Indonesia, jurnalisme damai mulai menjadi wacana yang ramai diperbincangkan pada saat maraknya kasus SARA di berbagai wilayah, terutama di awal 1990an, yang menyeruak di berbagai media dan membuat masyarakat menanggapinya dengan tergagap. Realitas ini bisa dimaklumi karena pada masa-masa sebelumnya (era Orba), aneka konflik tersembunyikan di bawah karpet tebal "persatuan dan kesatuan" dan diselesaikan dengan cara represi. Pihak yang berseteru dibungkam dan di level permukaan konflik didesain seolah sudah usai. Karenanya, letupan konflik SARA akhir-akhir ini tak ubahnya bom waktu yang secara akumulatif telah tertanam sejak lama.

Dalam kondisi sosial yang serbaburam tersebut, jurnalisme damai diharapkan menjadi salah satu referensi bagaimana seorang jurnalis mentransformasi realitas faktual sebagai realitas media. Bahwa media dan jurnalis bebas berekspresi adalah hal yang tiada terbantah, namun penting ditelisik apakah media sudah cukup dengan seperangkat pengetahuan dan pengalamannya selama puluhan tahun ditindas? Merespons meruyaknya tragedi kemanusiaan, rasanya "jurnalisme titik" (baca: konvensional, dengan matra pokok $5 \mathrm{~W}+1 \mathrm{H}$ ) tidak lagi memadai. Dalam situasi sosial yang carut-marut, jurnalisme tak bisa digunakan secara naif. Pada dimensi tertentu, jurnalisme damai menyuguhkan alternatif bagaimana jurnalis bekerja dalam situasi yang penuh tekanan dan sarat resiko.

Jack Lynch dan Annabel McGoldrick mewakili pangamat media yang projurnalisme damai mengemukakan bahwa pada kenyataannya tak semua media sudi menerima konsep jurnalisme damai. Banyak di antara pemilik media yang lebih senang menggunakan jurnalisme perang karena beragam sebab. Di antaranya dari segi ekonomi, jurnalisme perang lebih menjanjikan keuntungan profit. Paradigma jurnalisme ini lebih leluasa memotret -meminjam istilah antropolog E. Valentine Danielkekerasan yang telanjang (pornography of violence). Semakin variatif tindakan kekerasan, semakin panas sebuah pertikaian, maka ia kian meningkatkan animo publik terhadap media.

Bertolak pada pandangan ini, maka aspek nurani dan rasa peka kemanusiaan menjadi tidak begitu penting dilibatkan. Di aras inilah jurnalisme damai hendak mengetuk kesadaran akan pentingnya persaudaraan kemanusiaan sebagai sesama makhluk sosial. Kendati tetap memakai pola komprehensif cover botb sides (bahkan multi sides) sebagaimana jurnalisme baku pada umumnya, dalam jurnalisme damai, 
mind set (pola pandang) jurnalis dikerangkai oleh kehendak dan spirit untuk menyelesaikan setiap konflik secara damai. Karenanya ia membutuhkan tak hanya stamina, tapi juga compassion : pemahaman bahwa sebagai manusia kita seharusnya disatukan oleh rasa kemanusiaan kita serta kenyataan alamiah bahwa kita hidup di bumi yang serupa. ${ }^{24}$

Pendek kata, jurnalisme damai mengajak jurnalis untuk memahami konflik hingga ke dimensi terdalam yang bisa dirasakan. Karena itu, ada yang mengistilahkan jurnalisme demikian dengan 'jurnalisme analisis konflik' disebabkan dalam menjalankan tugasnya, jurnalis perlu memiliki pengetahuan seputar analisis konflik. Dengan begitu ia akan tahu apa saja yang mesti ia perbuat dan apa saja hal yang mesti dihindari. Tabel berikut kiranya bisa menjelaskan seputar simpul-simpul perbedaan tersebut.

\begin{tabular}{|c|c|}
\hline Jumalisme Mainstream & Jumalisme Alternatif \\
\hline $\begin{array}{l}\text { Peranan Jumalis } \\
\quad>\text { Watchdog } \\
>\text { Komentator } \\
>\text { Independen } \\
\quad>\text { Pengamat }\end{array}$ & 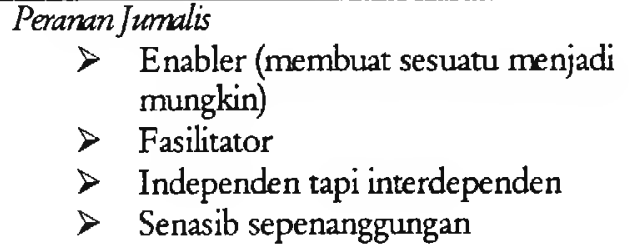 \\
\hline $\begin{array}{c}\text { Gaja Peradisan } \\
\text { - Debat } \\
\text { - Perbedaan } \\
\text { - Polemik }\end{array}$ & $\begin{array}{l}\text { Gaga Penulisan } \\
\text { - Dialog } \\
\text { - Persamaan dan perbedaan } \\
\text { - Diskusi }\end{array}$ \\
\hline $\begin{array}{l}\text { Pendekatan Jumalisme } \\
\text { Sederhana (bipolar) } \\
\text { Q Reaktif terhadap peristiwa } \\
\text { kekerasan } \\
\square \text { Menunggu terjadinya kekerasan } \\
\text { untuk bisa diliput } \\
\square \text { Fokus reportase pada peristiwa } \\
\square \text { “Saya obyektif” } \\
\square \text { Seimbang : meliput dari dua sisi } \\
\text { secara kuantitatif }\end{array}$ & $\begin{aligned} & \text { Pendekatan Jumalisme } \\
& \square \text { Menggali kekompleksan (multipolar) } \\
& \square \text { Strategi untuk mengerti atau } \\
& \text { membuka akar konflik } \\
& \square \text { Bersifat proaktif mencegah } \\
& \text { kekerasan terjadi } \\
& \square \text { Fokus reportase pada proses } \\
& \square \text { "Saya adil dan berimbang" } \\
& \square \text { Seimbang : meliput dari segala sisi } \\
& \text { secara kualitatif (corer multi sides) }\end{aligned}$ \\
\hline $\begin{array}{l}\text { Pendekatan Khalajak } \\
\checkmark \text { Kerusakan fisik, tubuh, } \\
\text { meningkatkan sirkulasi } \\
\checkmark \text { Kantor media menentukan agenda } \\
\checkmark \text { Pemimpin atau pakar yang paling } \\
\text { tahu segalanya (menyuarakan elite) } \\
\checkmark \text { Hak untuk tahu }\end{array}$ & $\begin{aligned} \text { Pendekatan Khalayak } \\
\checkmark \quad \text { Partisipasi publik dalam produksi } \\
\text { informasi } \\
\checkmark \quad \text { Masyarakat berperan } \\
\checkmark \quad \text { Menyuarakan mereka yang } \\
\\
\quad \text { terbisukan } \\
\checkmark \quad \text { Hak untuk berpartisipasi dalam } \\
\text { proses informasi }\end{aligned}$ \\
\hline
\end{tabular}

${ }^{24}$ Maria Hartiningsih, Jumalisme Damai multikultural, hal. 4. 
Dalam jurnalisme damai, seorang jurnalis dituntut memahami banyak hal, mulai dari akar konflik dan kekerasan, dampak sosial, metode pemecahan konflik (solusi), menyuarakan rekonstruksi, rekonsiliasi dan resolusi konflik, membantu menggelar dialog, serta menolong semua pihak terkait untuk mengubur dendam, memulihkan harapan dan menjalin persaudaraan damai. Jurnalisme damai menjadi satu di antara beberapa kunci strategis yang diharapkan mampu merangkai dialog antaragama, membina kerukunan, dan memelihara citra dan suasana keberagamaan yang meneduhkan. Menatap agenda antaragama ke depan, sudah waktunya media massa berpartisipasi secara kontributif melalui penerapan jurnalisme dialogis yang adil, terbuka, dan ramah kepada semua pihak.

\section{F. Penutup}

Bagaimanapun, ke depan dialog agama harus terus diupayakan. Kita mengharap bahwa dialog antaragama bukanlah sebatas perubahan tentang sistem substansial melalui ajaran, doktrin, maupun persamaan dan perbedaan antaragama, melainkan lebih pada bagaimana menempatkan agama sebagai sebab dan jalan keterbukaan bagi pihak lain. Oleh karenanya ia harus terus menerus didesain dan ditafsir ulang dengan cara yang lebih baru dan kontekstual.

Sebuah konteks yang dilukiskan Mohammed Arkoun sebagai peradaban di era "nalar grafis". Masyarakat modern saat ini, menurut Arkoun, disadari atau tidak, telah memiliki sebuah nalar khas masyarakat tulisan dengan wadahnya yang serba digital dan grafikal. Simtom nalar modern ini kemudian ditopang oleh fenomena mulai merebaknya institusi pers dan media massa yang "sedang tumbuh" dan kian matang. Kedewasaan fikir khalayak serta kematangan jurnalisme media menjadi modal penting bagi gelaran dialog dan harmoni antaragama di masa mendatang. Pada konteks inilah, wacana-wacana lintas agama menjadi urgen untuk melibatkan media sebagai kemasan ideal yang komunikatif. Mediapun diharapkan mampu menjadi penyangga bagi tegaknya cita reformasi multidimensional di negeri ini.

Dari alur argumen di muka, peran media dalam diskursus antaragama menjadi sesuatu yang penting dan strategis. Dengan segala potensi serta kekuatan yang dikandungnya, media bisa berfungsi sebagai agen bagi terwujudnya sirkulasi gagasan antaragama secara sejuk dan sehat. Media massa memiliki kekuatan untuk menumbuhkan, membentuk serta mengarahkan opini khalayak (public opinion) sebagai sebuah keyakinan atau pendirian yang lebih kokoh dan teruji dari sekadar prasangka atau rasa saling curiga. 
102 Millab Vol. IX, No. 1, Agustus 2009

\section{DAFTAR PUSTAKA}

Al-Qur'an al-Kariem

Abdalla, Ulil Abshar. Membakar Rumab Tuban: Pergulatan Agama Privat dan Publik. Bandung: Remaja Rosdakarya, 2000.

Effendy, Onong Uchyana. Ilmu Komunikasi: Teori dan Praktek. Bandung: Remaja Rosdakarya, 2000.

Hartiningsih, Maria. Jumalisme Damai Multikultural. Bogor: Makalah Diklat Jurnalisme Dakwah ICIP, 2005.

Meij, Dick Van der (ed.). Islam and the West: Obstacles and Solutions in Search for a New World Civilization. Jakarta: CLC UIN Jakarta dan Konrad-Adenauer Stiftung Coorporation, 2003.

Pareno; Sam Abede. Media Massa: Antara Realitas dan Mimpi. Surabaya: Penerbit Papyrus, 2005.

Piliang Yasraf Amir. Hipermoralitas: Mengadili Bayang-bayang. Yogyakarta: Penerbit Belukar, 2003.

Qodir, Zuly. Agama Dalam Bayang-Bayang Kekuasaan. Yogyakarta: Dian/Interfidei, 2001.

Sofyan, Muhammad. Agama dan Kekerasan dalam Bingkai Reformasi Jakarta: Yayasan Adikarya Ikapi-The Ford Fondation, 1999.

Sudibyo, Agus (et. al.). Kabar-kabar Kebencian: Prasangka Agama di Media Massa. Jakarta: ISAI, 2001.

- Politik Media dan Pertarungan Wacana. Yogyakarta: LkiS, 2001.

Suseno, Franz Magnis. Etika Jawa: Sebuab Analisa Filsafatitentang Kebijaksanaan Hidup Jawa. Jakarta: Gramedia Pustaka Utama, 1985.

\section{Media Cetak:}

Koran Tempo, 02 Mei 2004.

Kompas, 30 Agustus 2003, 02 November 2000, 04 Mei 2001, 05 Agustus 2000, 08 Mei 2005, 09 Februari 1999, 05 Mei 2005. 